\title{
Determination of cardinal temperatures for sugar apple (Annona squamosa L.)
}

\section{Determinação de temperaturas cardinais em pinheira (Annona squamosa L.)}

\author{
Bruno Rafael Alves Rodrigues ${ }^{1}$, Rayane Carneiro dos Santos ${ }^{1}$, Silvia Nietsche ${ }^{1 *}$, \\ Maria Olívia Mercadante-Simões², Isabella Renata Gomes da Cunha², \\ Marlon Cristian Toledo Pereira ${ }^{1}$
}

\author{
Universidade Estadual de Montes Claros/Unimontes, Departamento de Ciências Agrárias/DCA, Janaúba, MG, Brasil \\ ¿Universidade Estadual de Montes Claros/Unimontes, Departamento de Biologia Geral, Montes Claros, MG, Brasil \\ *Corresponding author: silvia.nietsche@unimontes.br \\ Received in october 27, 2015 and approved in december 22, 2015
}

\begin{abstract}
The sugar apple is highly dependent on the pollination and fruit tree pollen performance is crucial for successful fertilization and fruit set. The objective of this study was to determine the cardinal temperatures for in vitro pollen grains germination and evaluate the effect of temperature on pollen tube growth of sugar apple. The experimental design was in a completely randomized with eight treatments (10, $15,20,25,30,35,40$ and $45^{\circ} \mathrm{C}$ ), four replicates and each plot was constituted by two slides per parcel. The cardinal temperatures were determined by evaluating in vitro germination of pollen grains and pollen tube growth in standard culture medium. It also assessed the pollen tube growth and the percentage of germination in vitro depending on the type of pollen grain arrangement (monad, dyad, triad and tetrad). In vitro germination of pollen grains and pollen tube growth varied significantly with temperature. The maximum germination recorded $(48.13 \%)$ and the maximum lengths of pollen tubes $(536.45 \mu \mathrm{m})$ were obtained when pollen grains were cultivated at $25^{\circ} \mathrm{C}$. The estimated cardinal temperatures were $9.7,26.9$ and $44.2^{\circ} \mathrm{C}$. Among the pollen grain arrangements, tetrads pollen grains were observed in higher proportions, however, monads pollen grains presented higher germination percentage.
\end{abstract}

Index terms: In vitro germination; pollen viability; monads; tetrads; pollen tube.

\begin{abstract}
RESUMO
A pinheira é uma fruteira altamente dependente da polinização e o desempenho do pólen é determinante para o sucesso da fertilização e frutificação efetiva. O objetivo deste trabalho foi determinar as temperaturas cardinais para a germinação in vitro dos grãos de pólen e avaliar o efeito de diferentes temperaturas no crescimento dos tubos polínicos de pinheira. O delineamento experimental foi o inteiramente casualizado, com oito tratamentos $\left(10,15,20,25,30,35,40\right.$ e $\left.45^{\circ} \mathrm{C}\right)$, quatro repetições, sendo cada parcela experimental constituída por duas lâminas. As temperaturas cardinais foram determinadas por meio da avaliação da germinação in vitro dos grãos de pólen e do crescimento do tubo polínico em meio de cultura padrão. Avaliou-se também o crescimento do tubo polínico e o percentual de germinação in vitro em função do tipo de arranjo do grão de pólen (mônade, díade, tríade e tétrade germinados). A germinação in vitro dos grãos de pólen e o crescimento dos tubos polínicos da pinha variou significativamente com a temperatura. A máxima germinação in vitro registrada $(48,13 \%)$ e o máximo comprimento dos tubos polínicos $(536,45 \mu \mathrm{m})$ foram obtidos quando os grãos de pólen foram cultivados a $25^{\circ} \mathrm{C}$. As temperaturas cardinais estimadas foram 9,7, 26,9 e 44,2 ${ }^{\circ} \mathrm{C}$. Dentre os arranjos de grãos de pólen, foi observada maior percentagem de tétrades, no entanto, os grãos de pólen do tipo mônades apresentaram maiores porcentagem de germinação.
\end{abstract}

Termos para indexação: Germinação in vitro; viabilidade polínica; mônades; tétrades; tubo polínico.

\section{INTRODUCTION}

The use of artificial pollination in species of the family Annonaceae, particularly in sugar apple, has significantly increased the productivity of these species. Artificial pollination increases the size, regulates the shape and improves various other physical and chemical characters of the fruit (Campos et al., 2004). Although our understanding of floral biology and artificial pollination methodologies have advanced in recent years, some of the main obstacles to cultivation are still the low indices of fruit-set of the flowers and their subsequent development into fruit (Mendes et al., 2012; Pereira et al., 2014; Santos et al., 2014).

Studies indicate that the low number of carpels fertilized in sugar apple flowers is associated with the low viability of pollen grains during some seasons of the year. In turn, the viability of the pollen grains can be affected by various factors, such as plant genotype, nutritional 
conditions, variation in moisture levels and ambient temperature (Bettiol Neto et al., 2009).

Problems arising from extremely high or extremely low temperatures impact the reproductive tissues of plants, affecting the male and female structures differently. Several studies have focused on the effect of temperature during microsporogenesis because the pollen grain is likely to be more sensitive to environmental stress compared to the ovule (Hedhly et al., 2008; Prasad et al., 2011).

The stress cause by temperature may reduce the number of pollen grains and their viability. Even cases of moderate temperature changes can lead to problems during fertilization. In cases of extreme temperature change, complete sterility of the pollen grain and/or inhibition of anther dehiscence are observed, resulting in the absence of fructification. In the post-pollination stage, temperature can also reduce fertility and affect pollen tube growth (Hedhly, 2011). During the progamic stage, temperature affects both pollen germination and the kinetics of pollen tube growth in the style. Studies with different species have attempted to understand the consequences of temperature changes on pollen grain germination. However, this effect is variable and depends on the species or cultivar studied (Sukhvibul et al., 2000).

This subject has been studied in several different crops such as pistachios (Acar and Kakami, 2010), peaches (Hedhly et al., 2005), peanuts (Kakani et al., 2002), cotton (Kakani et al., 2005), sorghum (Prasad et al., 2011), Capsicum (Reddy and Kakani, 2007) and papaya (Tamaki et al., 2011). Based on their findings, these authors have defined the cardinal temperatures: the minimum temperature $\left(\mathrm{T}_{\min }\right)$ at which pollen grains germinate, the optimal temperature at which the pollen grain germination reaches the maximum $\left(\mathrm{T}_{\mathrm{opt}}\right)$ and the maximum temperature $\left(\mathrm{T}_{\max }\right)$ after which pollen grain germination does not occur.

Few studies have been conducted on the response of pollen grain germination and pollen tube growth in response to varying germination temperatures in species of the family Annonaceae. The cardinal temperatures $\left(\mathrm{T}_{\text {min, }} \mathrm{T}_{\text {opt }}\right.$ and $\left.\mathrm{T}_{\max }\right)$ for the maximum percentage of pollen germination and maximum length of the pollen tube also have not been reported for Annona squamosa. These studies are fundamentally important for supporting to sustain genetic breeding programs and for proper cultivation management practices, especially in semi-arid regions of Brazil.

Thus, the present study aimed to determine the cardinal temperatures for the in vitro germination of sugar apple pollen grains, analyze the effects of different temperatures on the in vitro germination of the pollen grains and pollen tube length and characterize the types of pollen grain arrangements in the sugar apple.

\section{MATERIAL AND METHODS}

The experiment was conducted in the Laboratory of Biotechnology, Department of Agricultural Sciences and in the Laboratory of Plant Anatomy, Department of Biology at Montes Claros State University (Unimontes) in Montes Claros, MG, Brazil.

Sugar apple flowers in the functional pistillate stage from a commercial orchard located in the municipality of Janaúba, MG, latitude $15^{\circ} 52^{\prime} 7^{\prime \prime} \mathrm{S}$ and $43^{\circ} 19^{\prime} 42^{\prime \prime} \mathrm{W}$ were collected from the field at 4:00 pm the day before and carried to the laboratory. The flowers were maintained in paper bags in the laboratory at room temperature $\left(25^{\circ} \mathrm{C}\right)$ and a relative humidity of $50 \%$ during 14 hours, until they reached the functional staminate stage with the release of pollen grains.

The experiment was conducted using a completely randomized design with eight treatments, consisting of eight different temperatures $(10,15,20,25,30,35,40$ and $45^{\circ} \mathrm{C}$ ), four replicates and two slides for each parcel. Studies to determine the cardinal temperatures were performed by evaluating the in vitro germination of pollen grains and pollen tube growth in standard culture medium (without a gelling agent) containing $1.27 \mathrm{mM} \mathrm{Ca}\left(\mathrm{NO}_{3}\right)_{2}$ $4 \mathrm{H}_{2} \mathrm{O}, 0.87 \mathrm{mM} \mathrm{MgSO}{ }_{4} 7 \mathrm{H}_{2} \mathrm{O}, 0.99 \mathrm{mM} \mathrm{KNO}_{3}, 1.62$ $\mathrm{mM} \mathrm{H}_{3} \mathrm{BO}$ and $100 \mathrm{~g} \mathrm{~L}^{-1}$ sucrose (Brewbaker and Kwack, 1963) at $\mathrm{pH}$ 7.0. The culture medium was sterilized in an autoclave at $120^{\circ} \mathrm{C}$ for 20 minutes. The solution was stored in a flask in the refrigerator for subsequent use.

The pollen grains were removed from the anthers by using a number 2 water color paint brush and were inoculated into the center of a glass plate containing $200 \mu \mathrm{L}$ of standard culture medium. After inoculation, the slides were placed in Petri dishes with moist filter paper, which formed a moist chamber, and then were incubated in camera type BOD with temperature-controlled ranging from $10{ }^{\circ} \mathrm{C}$ to $45^{\circ} \mathrm{C}$ at $5{ }^{\circ} \mathrm{C}$ intervals, as described above.

After six hours of incubation, the germinated pollen grains were estimated under a bright field microscope using a low magnitude objective (10x). A total of 100 randomly selected pollen grains were counted per slide. Pollen grains were considered germinated when the width of the pollen tube was longer than its diameter (Acar and Kakani, 2010). The percent in vitro germination of pollen grains was estimated using the ratio between the number of germinated pollen grains and the total number of pollen grains counted on each slide. 
The type of arrangement of the custard apple pollen grains was also evaluated for each slide. The percentage was determined based on the ratio of each type of arrangement and the total number of pollen grains. The percent in vitro germination was also evaluated as a function of the type of pollen grain arrangement, where the number of germinated monad, dyad, triad and tetrad pollen grains was counted on each slide.

Morphometric analyses were used to evaluate the effect of temperature on pollen tube growth. The slides were stained with toluidine blue and photographed with a Nikon 200 microscope equipped with a digital camera. Photomicrographs were used to determine the length of the pollen tubes using the UTHSCSA - ImageTool image analysis software. The mean length of the pollen tubes was calculated as the mean length of ten pollen tubes from each slide using the Image-Pro Plus software.

Analysis of variance was used to analyze the data using SISVAR statistical software, and the means between conditions were compared using regression analysis and Tukey's test at $1 \%$ probability.

The in vitro germination and pollen tube length data in response to temperature were used to estimate the cardinal temperatures, that is, $\mathrm{T}_{\min }$ (minimum temperature at which the pollen grain germinates), $\mathrm{T}_{\mathrm{opt}}$ (optimal temperature at which the pollen grain reaches maximum germination) and $\mathrm{T}_{\max }$ (maximum temperature above which pollen grain does not germinate), and these were analyzed using linear and nonlinear regression models that are widely used in these studies (Acar and Kakani, 2010; Salem et al., 2007). The adjustments of the regression equations, which describe the response of pollen germination to temperature, were compared by the variance explained by the coefficient of determination $\left(\mathrm{R}^{2}\right)$ and the standard error. The highest $\mathrm{R}^{2}$ value and the lowest standard error were used to select the most appropriate regression model for the data.

The parameters of the quadratic nonlinear regression model (Equation 1) were used, where $\mathrm{T}$ is the temperature relative to the treatment, and $\mathrm{a}, \mathrm{b}$, and $\mathrm{c}$ are regression parameters for each treatment generated using SISVAR. Thus, the minimum $\left(\mathrm{T}_{\text {min }}\right)$, optimum $\left(\mathrm{T}_{\text {opt }}\right)$ and maximum $\left(\mathrm{T}_{\max }\right)$ temperatures were estimated as described by Acar and Kakani (2010) and Salem et al. (2007) using Equations 2, 3 and 4.

Pollen grain germination $=\mathrm{a}+\mathrm{bT}+\mathrm{cT}^{2}$

$\mathrm{T}_{\min .}=\frac{-\mathrm{b}}{2 \mathrm{c}}$

$$
\begin{aligned}
& T_{\text {opt. }}=\frac{-b+\sqrt{b^{2} \cdot 4 \cdot a \cdot c}}{2 c} \\
& T_{\max .}=\frac{-b-\sqrt{b^{2} \cdot 4 \cdot a \cdot c}}{2 c}
\end{aligned}
$$

\section{RESULTS AND DISCUSSION}

The analysis of variance of the in vitro pollen grain germination and pollen tube length data showed a significant difference at a $1 \%$ probability level for the variations in temperature (Table 1). The mean diameter observed for the sugar apple pollen grains was $40.5 \mu \mathrm{m}$ (data not shown). The maximum germination recorded was $48.13 \%$, which was achieved when the pollen grains were cultured at $25^{\circ} \mathrm{C}$ (Table 1). In general, at extremely high or low temperatures, germination of the pollen grains was reduced $\left(10,15\right.$ and $\left.40{ }^{\circ} \mathrm{C}\right)$ or not observed at all $\left(45^{\circ} \mathrm{C}\right)$ (Table 1$)$.

Although there not have not been many reports in the literature on this topic for Annonaceae family, Rosell et al. (1999), worked with the effects of temperature on pollen grain germination for cherimoya, observed that in the range of $20-30{ }^{\circ} \mathrm{C}$, the percent germination was higher (47-35\%), and at temperatures below $15{ }^{\circ} \mathrm{C}$ and above $30{ }^{\circ} \mathrm{C}$, the rates of pollen grain germination rates decreased considerably.

For $A$. squamosa, studies on this subject are also more limited. Bettiol Neto et al. (2009), studied the pollen grain collection periods of this specie in an orchard located in Lins, São Paulo state, and reported a mean percent germination of $37.6 \%$ for ambient temperatures associated with a relative humidity above $80 \%$. In contrast, when pollen grains were collected during periods of low relative humidity ( $53 \%$ and $43 \%$ ), the mean percent germination dropped to $21.18 \%$.

The results of the present study demonstrate that pollen tube growth was also significantly affected by the different temperatures (Table 1). Low temperatures, 10 and $15{ }^{\circ} \mathrm{C}$, reduced the elongation of pollen tubes, which produced mean lengths of 74.34 and $107.37 \mu \mathrm{m}$, respectively. An increase in the pollen tube length was observed starting at $20{ }^{\circ} \mathrm{C}$ temperatures $(255.42 \mu \mathrm{m})$, and maximum pollen tube lengths were observed when incubated at a temperature of $25^{\circ} \mathrm{C}(536.45 \mu \mathrm{m})$. At temperatures above $30^{\circ} \mathrm{C}$, the pollen tube length started to be affected again, showing significant decreases (Table 1, Figure 1). 
Table 1: Percentage of germination of pollen grains and pollen tube length of sugar apple in response to temperature.

\begin{tabular}{ccc}
\hline Temperature $\left({ }^{\circ} \mathrm{C}\right)$ & Germination $(\%)$ & Pollen tube length $(\mu \mathrm{m})$ \\
\hline 10 & $0.88 \mathrm{E}$ & $74.34 \mathrm{D}$ \\
15 & $13.13 \mathrm{D}$ & $107.37 \mathrm{D}$ \\
20 & $29.13 \mathrm{C}$ & $255.42 \mathrm{~B}$ \\
25 & $48.13 \mathrm{~A}$ & $536.45 \mathrm{~A}$ \\
30 & $36.88 \mathrm{~B}$ & $276.41 \mathrm{~B}$ \\
35 & $24.88 \mathrm{C}$ & $239.85 \mathrm{BC}$ \\
40 & $1.00 \mathrm{E}$ & $204.00 \mathrm{C}$ \\
45 & $0.00 \mathrm{E}$ & $0 \mathrm{E}$ \\
\hline $\mathrm{CV}(\%)$ & 15.89 & 9.69 \\
\hline
\end{tabular}

Means followed by the same letter are not significantly different by Tukey's test at $1 \%$ probability.

An effect of temperature on pollen tube growth in $A$. cherimola was also observed. Temperatures between $20^{\circ} \mathrm{C}$ and $25^{\circ} \mathrm{C}$ favor the formation of well-developed pollen tubes, whereas at temperatures below $15^{\circ} \mathrm{C}$, pollen tube growth was slower and pollen tube length was reduced. In addition, the authors noted that some pollen tubes were swollen and had altered shapes. At higher temperatures $\left(30^{\circ} \mathrm{C}\right)$, pollen tubes were longer, but the pollen grains appeared to be less hydrated (Rosell et al., 1999).

The effects of temperature on the development of pollen tubes have also been observed in other species. Tamaki et al. (2011) evaluated the effects of seven constant temperatures in papaya and reported significant differences in the growth of pollen tubes. According to the authors, most well-developed pollen tubes were observed at $25^{\circ} \mathrm{C}$, followed by $20,30,15$ and $35^{\circ} \mathrm{C}$, whereas the shortest pollen tube lengths were observed at $40^{\circ} \mathrm{C}$.

Temperature is considered one of the environmental factors that most influences the reproductive process of plants (Kakani et al., 2005). To test the response of in vitro pollen grain germination and pollen tube growth, studies examining variations in temperature and the use of linear and non-linear regression models have been widely used.

As with any biological system, increases in temperature result in an increase in the rate of a reaction within specific limits for progression. High temperatures between $20^{\circ} \mathrm{C}$ and $30^{\circ} \mathrm{C}$ are more important for germination and elongation of the pollen grain tubes of custard apples compared to lower temperatures, but germination and growth are affected above $30{ }^{\circ} \mathrm{C}$, with higher temperatures being detrimental (Figures 2 and 3). This can be explained because at low temperatures, enzymatic reactions slow down due to a drop in kinetic energy, reducing the cellular metabolism of pollen grains (Cuchiara et al., 2012). Increasing the temperature can accelerate the rate of a reaction up to a certain limit, but after this limit is reached, complete enzyme denaturation occurs (Taiz and Zeiger, 2013).

Studies conducted under controlled conditions suggest that high temperatures are more harmful when flowers emerge (flower initiation), and this sensitivity continues for 10 to 15 days (Wahid et al., 2007). The reproductive stages that are most sensitive to high temperature in various plants include gametogenesis (8-9 days prior to anthesis) and fertilization (1-3 days after anthesis). Reductions in fruit quantity due to temperature increases have been reported for some species, including apricots (Rodrigo and Herrero, 2002), cherries (Hedhly et al., 2007) and peaches (Kozai et al., 2004).

Although a certain temperature range may be adequate for germination and pollen tube growth, knowledge of the cardinal temperatures for particular characteristics in a given species is important. Temperature fluctuations outside the tolerance limit exhibited by a species can affect pollen grain germination and significantly affect production and productivity (Hedhly, 2011).

The current study examined the response of pollen grains at temperatures ranging from 10 to $45^{\circ} \mathrm{C}$ and clearly indicated that the pollen grain germination process and pollen tube growth can also be described in terms of temperature. The optimum temperature, the minimum temperature and the maximum temperature for custard apples were determined using quadratic regression models (Figures 2 and 3). 


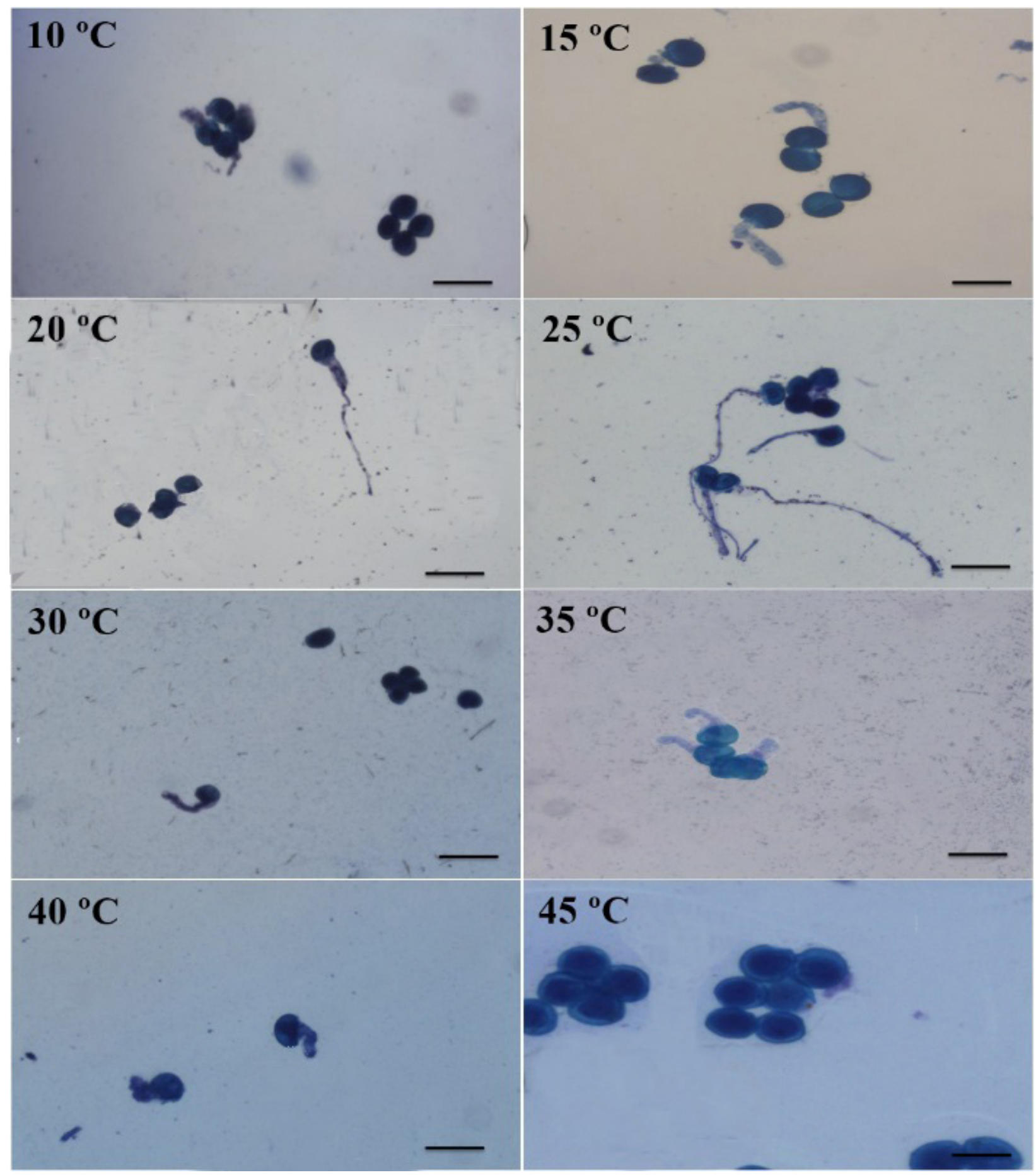

Figure 1: Effect of temperature on in vitro germination of sugar apple pollen grains. Pollen grains incubated at $10^{\circ} \mathrm{C}, 15^{\circ} \mathrm{C}, 20^{\circ} \mathrm{C}, 25^{\circ} \mathrm{C}, 30^{\circ} \mathrm{C}, 35^{\circ} \mathrm{C}, 40^{\circ} \mathrm{C}$ and $45^{\circ} \mathrm{C}$. Bar $=100 \mu \mathrm{m}$. 


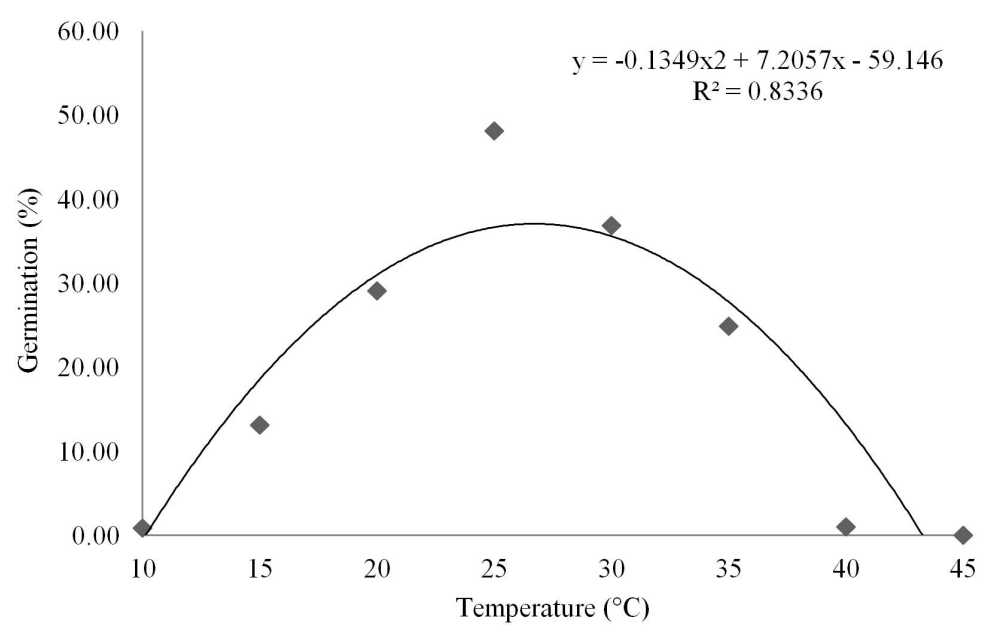

Figure 2: Percentage of germination of sugar apple pollen grains in response to different temperatures.

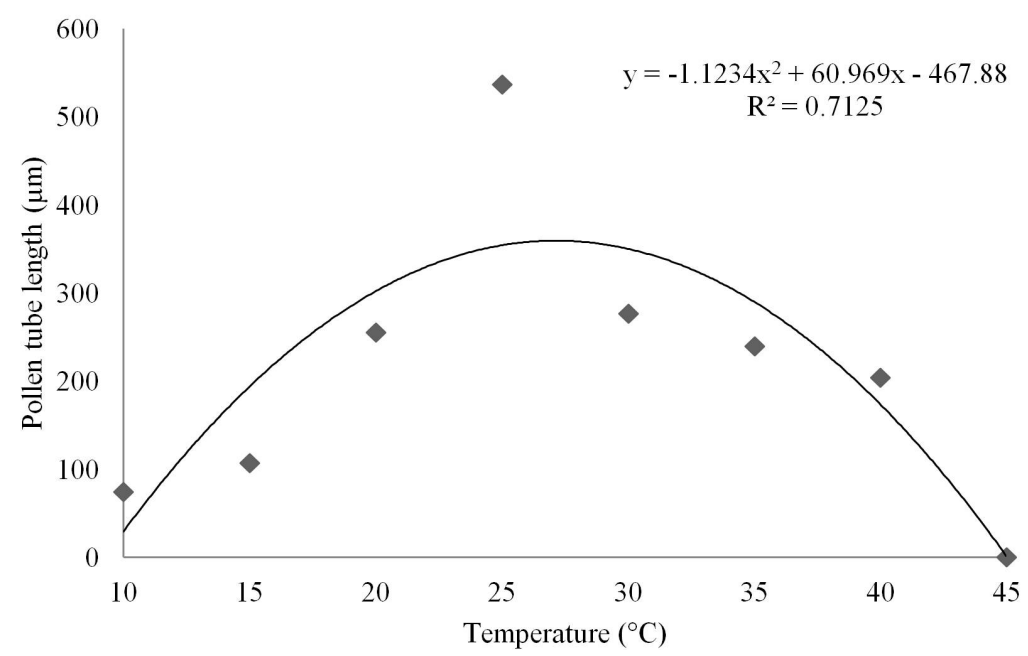

Figure 3: Pollen tube length of sugar apple in response to different temperatures.

The cardinal temperatures were determined from the data on pollen germination and pollen tube growth. The minimum temperatures $\left(\mathrm{T}_{\min }\right)$ were $10.1{ }^{\circ} \mathrm{C}$ and $9.3{ }^{\circ} \mathrm{C}$, respectively. The maximum temperatures $\left(\mathrm{T}_{\max }\right)$ were $43.3^{\circ} \mathrm{C}$ and $45.0^{\circ} \mathrm{C}$, respectively and the optimal temperature $\left(\mathrm{T}_{\mathrm{opt}}\right)$ for maximum pollen germination and pollen tube growth were $26.7^{\circ} \mathrm{C}$ and $27.1^{\circ} \mathrm{C}$, respectively (Table 2).

The minimum and maximum temperatures observed in the present study allow us to infer the tolerance range in which the sugar apple pollen grain maintains its ability to germinate and achieves optimal pollen tube growth.

The temperatures observed in the present study were similar to those reported by various researchers for pollen from other species. In genotypes of different Capsicum species, mean in vitro germination rates of $77.8 \%$ were observed for pollen grain from seven species, and the mean cardinal temperatures observed for all genotypes were $\mathrm{T}_{\text {min }}=15.2^{\circ} \mathrm{C}, \mathrm{T}_{\text {opt }}=30.7^{\circ} \mathrm{C}$ and $\mathrm{T}_{\text {max }}=41.8^{\circ} \mathrm{C}$ (Reddy and Kakani, 2007).

In studies examining genotypes of the genus Pistacia, the mean minimum, optimum and maximum cardinal temperatures observed for all genotypes were $6.7^{\circ} \mathrm{C}, 23.9^{\circ} \mathrm{C}$ and $41.1{ }^{\circ} \mathrm{C}$, respectively. In the same study, a cumulative response index to temperature was used to identify species/genotypes that are sensitive, intermediate and tolerant to high temperatures (Acar and Kakani, 2010). 
Table 2: Cardinal temperatures for the in vitro germination and pollen tube growth of sugar apple.

\begin{tabular}{cccc}
\hline \multirow{2}{*}{ Characteristics } & \multicolumn{3}{c}{ Cardinal temperatures $\left({ }^{\circ} \mathrm{C}\right)$} \\
\cline { 2 - 4 } & $\mathrm{T}_{\min }$ & $\mathrm{T}_{\mathrm{opt}}$ & $\mathrm{T}_{\max }$ \\
\hline Pollen germination & 10.1 & 26.7 & 43.3 \\
Pollen tube growth & 9.3 & 27.1 & 45.0 \\
Mean & 9.7 & 26.9 & 44.2 \\
\hline
\end{tabular}

Minimum temperature $\left(T_{\text {min }}\right)$, optimal temperature $\left(T_{\text {opt }}\right)$ and maximum temperature $\left(T_{\text {max }}\right)$.

The characteristics of pollen grains identified in the present study can be used as parameters in breeding programs for selecting genotypes for specific environments. According to Reddy and Kakani (2007), the heat tolerance of pollen grain is essential in the current climate as well as in future climates, which are projected to be warmer and more variable.

The cardinal temperatures can affect two important factors in fruit crop production: the recommendation of the future establishment of orchards and the irrigation management during the pollination season. Saavedra (1977) noted that spraying water on recently pollinated cherimoya flowers increased the fruit set. The author attributed this increased fruit set to reductions in the effects of dehydration on the flower's pollen and stigma.

Using optical microscopy, different arrangements of pollen grains were identified. As a result of the morphometry analysis, both individual pollen grains, denoted as monads (Figure 4A), and the formation of groups of pollen grains in the form of dyads, triads and tetrads were noted for custard apples (Figures 4B, 4C and 4D).

Pollen grain counts were performed regardless of the pollen grain arrangement (Figures 4A, 4B, 4C and 4D). On average, the frequency of the different arrangements was approximately $22 \%$ monads, $25.3 \%$ dyads, $3.0 \%$ triads and $49.7 \%$ tetrads.

The number of tetrads was relatively high in the pollen grain samples under study. According to Copenhaver (2005), the formation of tetrads is most common in Annonaceae. This type of formation appears to have biological implications given that tetrads can be related to specific pollinators such as beetles because, in general, Annonaceae pollen is "heavy" and "sticky" (Bettiol Neto et al., 2009).

The release of tetrad pollen grains by insect pollinators could increase the efficiency of pollination because four pollen grains could be transferred in a single visit by pollinators. Accordingly, a correlation has been demonstrated between pollen grain tetrads and a high number of fertilized ovules in Annonaceae (Walker, 1971). According to Harder and Johnson (2008), the release of pollen grain tetrads is more advantageous in situations where pollinators are more common.

One additional benefit to the formation of pollen grain arrangements is the protection against desiccation and against the entry of pathogens through the thin walls of the pollen opening. Pollen grouped in dyads, triads or tetrads have strong proximal exine reductions in Annonaceae (Le Thomas et al., 1986).

The analysis of variance revealed that the interaction between the input factors of pollen arrangement and incubation temperature was significant for the percent germination variable. At a temperature of $45^{\circ} \mathrm{C}$, no pollen grains germinated, and at temperatures of $10{ }^{\circ} \mathrm{C}$ and $40{ }^{\circ} \mathrm{C}$, only monad pollen grains germinated. Germination occurred for all the different types of pollen grain arrangements at all the remaining temperatures examined (Figure 5).

The pollen grains that formed monads had the highest percentage of germination for all the temperatures examined, except at $30{ }^{\circ} \mathrm{C}$, where the percent germination for monads was not significantly higher than the percent germination of the dyads (Figure $5)$.

We observed that custard apple pollen grains were very sensitive to variations in temperature. Significant changes in the pollen grain germination and pollen tube growth were described here. These results confirm the high sensitivity of male gametes of this species, indicating that particular attention should be given to pollen grain management to increase the fruit set and fruit quality of custard apples. 


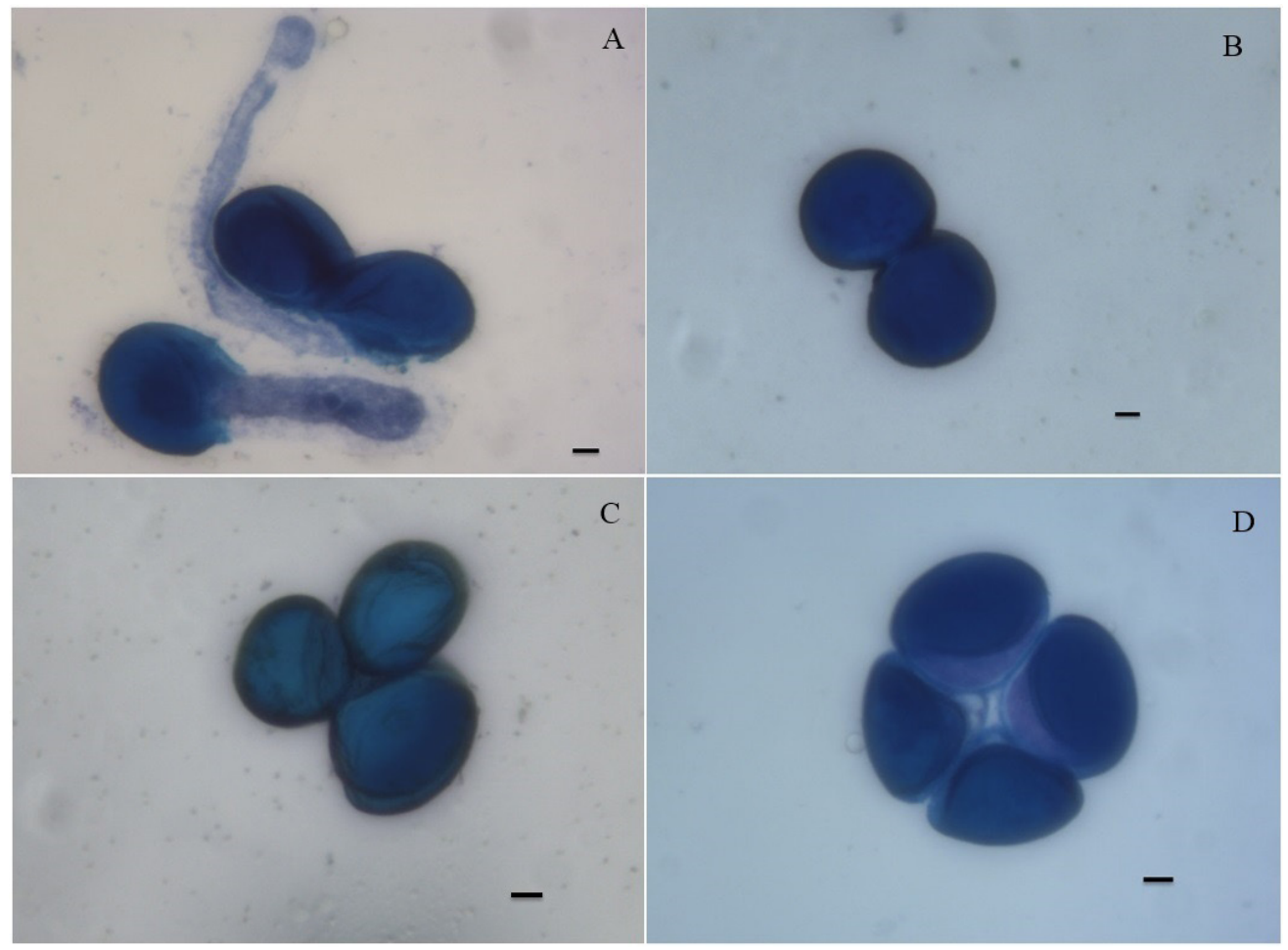

Figure 4: Types of pollen grain arrangements for Annona squamosa. (A) Monad; (B) Dyad; (C) Triad; (D) Tetrad. Bar $=100 \mu \mathrm{m}$.

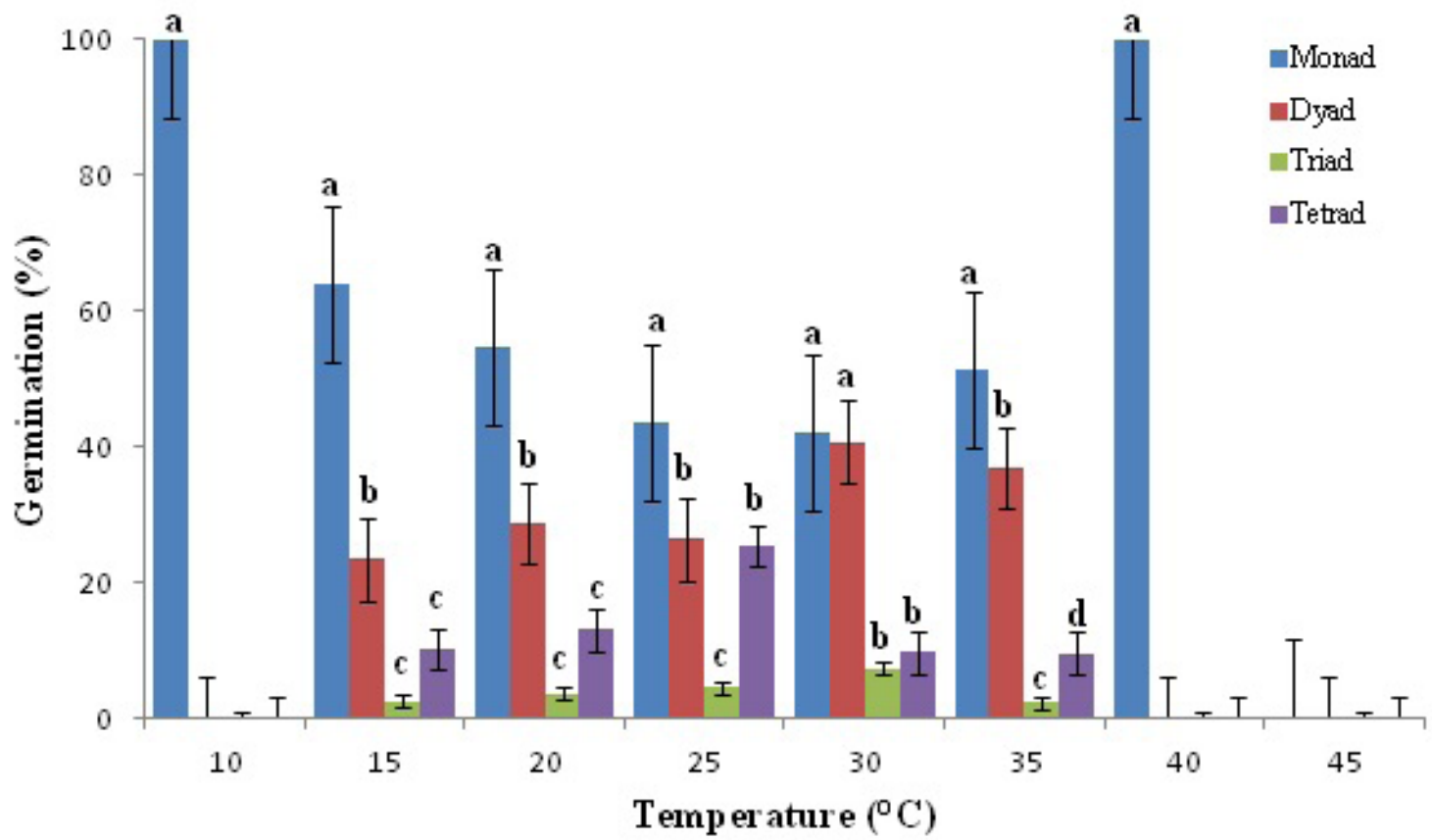

Figure 5: Interaction between the different types of pollen arrangements (monads, dyads, triads and tetrads) and the temperature in the germination of custard apple pollen grains. 


\section{CONCLUSIONS}

Temperatures at $25^{\circ} \mathrm{C}$ yield higher percentages of pollen grain germination and longer pollen tube lengths in in vitro conditions. The cardinal temperatures $\left(\mathrm{T}_{\text {min }}, \mathrm{T}_{\mathrm{opt}}\right.$ and $\mathrm{T}_{\max }$ ) for the pollen grain germination and pollen tube growth for sugar apple in in vitro are 9.7, 26.9 and $44.2{ }^{\circ} \mathrm{C}$, respectively. The sugar apple has a higher percentage of pollen grain tetrads, but the monads have a higher percentage of germination.

\section{REFERENCES}

ACAR, I.; KAKANI, V. G. The effects of temperature on in vitro pollen germination and pollen tube growth of Pistacia spp. Scientia Horticulturae, 125(4):569-572, 2010.

BETTIOL NETO, J. E. et al. Viabilidade e conservação de pólen de três anonas comerciais. Bragantia, 68(40):825-837, 2009.

BREWBAKER, J. L.; KWACK, B. H. The essential role of calcium ion in pollen germination and pollen tube growth. American Journal of Botany, 50(9):859-865, 1963.

CAMPOS, R. S. et al. Polinização natural, manual e autopolinização no pegamento de frutos de pinheira (Annona squamosa L.) em Alagoas. Revista Brasileira de Fruticultura, 26(2):261-263, 2004.

COPENHAVER, G. P. A compendium of plant species producing pollen tetrads. Journal of the North Carolina. Academy of Science, 121(1):17-35, 2005.

CUCHIARA, C. C.; SILVA, S. D. A.; BOBROWSKI, V. L. Conservação de grãos de pólen de mamoeira a baixas temperaturas. Revista Ceres, 59(1):82-87, 2012.

HARDER, L.; JOHNSON, S. Function and evolution of aggregated pollen in angiosperms. International Journal of Plant Sciences, 169(1):59-78, 2008.

HEDHLY, A. Sensitivity of flowering plant gametophytes to temperature fluctuations. Environmental and Experimental Botany, 74(1):9-16, 2011.

HEDHLY, A.; HORMAZA, J. I.; HERRERO, M. The effect of temperature on pollen germination, pollen tube growth and stigmatic receptivity in peach (Prunus persica L. Batsch.). Plant Biology, 7(5):476-483, 2005.

HEDHLY, A.; HORMAZA, J. I.; HERRERO, M. Warm temperatures at bloom reduce fruit set in sweet cherry. Journal of Applied Botany and Food Quality, 81(2):158-164, 2007.
HEDHLY, A.; HORMAZA, J. I.; HERRERO, M. Global warming and plant sexual reproduction. Trends in Plant Science, 14(1):30-36, 2008.

KAKANI, V. G. et al. Response of in vitro pollen germination and pollen tube growth of groundnut (Arachis hypogaea L.) genotypes to temperature. Plant, Cell \& Environment, 25(12):651-661, 2002.

KAKANI, V. G. et al. Differences in vitro pollen germination and pollen tube growth of cotton cultivars in response to high temperature. Annals of Botany, 96(1):59-67, 2005.

KOZAI, N. et al. Adverse effects of high temperature on the development of reproductive organs in 'Hakuho' peach trees. Journal of Horticultural Science and Biotechnology, 79(4):533-537, 2004.

LE THOMAS, A.; MORAWETZ, W.; WAHA, M. Pollen of paleo and neotropical Annonaceae: definition of the aperture by morphological and functional characters. In: BLACKMORE, S.; FERGUSON, I. K. Pollen and Spores: Form and Function. London, UK: Academic Press,1986. p.375-388.

MENDES, H. T. A. et al. Pollen grain germination and fruit set in 'Brazilian seedless' sugar apple (Annona squamosa L.). Crop Breeding and Applied Biotechnology, 12(4):277280, 2012.

PEREIRA, M. C. T. et al. Effects of storage length and flowering stage of pollen influence its viability, fruit set and fruit quality in 'Red' and 'Lessard Thai' sugar apple (Annona squamosa) and 'Gefner' atemóia (A. cherimola $\times A$. squamosa). Scientia Horticulturae, 178(1):55-60, 2014.

PRASAD, P. V. V.; BOOTE, K. J.; ALLEN, J. R. L. H. Longevity and temperature response of pollen as affected by elevated growth temperature and carbon dioxide in peanut and grain sorghum. Environmental and Experimental Botany, 70(1):51-57, 2011.

REDDY, K. R.; KAKANI, V. G. Screening Capsicum species of different origins for high temperature tolerance by in vitro pollen germination and pollen tube length. Scientia Horticulturae, 112(2):130-135, 2007.

RODRIGO, J.; HERRERO, M. Effects of pre-blossom temperatures on flower development and fruit set in apricot. Scientia Horticulturae, 92(2):125-135, 2002.

ROSELL, P.; HERRERO, M.; SAÚCO, V. G. Pollen germination of cherimoya (Annona cherimola (Mill.)). In vivo characterization and optimization of in vitro germination. Scientia Horticulturae, 81(3):251-265, 1999. 
SAAVEDRA, E. Influence of pollen grain stage at time of hand pollination as a factor on fruit set of cherimoya. HortScience, 12(2):117-118, 1977.

SALEM, M. A. Pollen-based screening of soybean genotypes for high temperatures. Crop Science, 47(1):219-231, 2007.

SANTOS, R. C. dos et al. Stenospermy and seed development in the "Brazilian seedless" variety of sugar apple (Annona squamosa). Anais da Academia Brasileira de Ciências, 86(4):2101-2108, 2014.

SUKHVIBUL, N. et al. E. Effect of temperature on pollen germination and pollen tube growth of four cultivars of mango (Mangifera indica L.). Journal of Horticultural Science and Biotechnology, 75(2):64-68, 2000.
TAIZ, L.; ZEIGER, E. Fisiologia Vegetal. Porto Alegre. Artmed, 2013. 722 p.

TAMAKI, M. et al. Seasonal variations in pollen germination ability, reproductive function of pistils, and seeds and fruit yield in papaya (Carica papaya L.) in Okinara. Journal of Japanese Society of Horticulture Science, 80(2):156163, 2011.

WAHID, A. et al. Heat tolerance in plants: an overview. Environmental Experimental Botany, 61(3):199-223, 2007.

WALKER, J. W. Pollen morphology, phytogeography and phylogeny of the Annonaceae. Contributions for the Gray Herbarium, 202:1-130, 1971. 